\title{
KARAKTERISTIK CAIRAN RUMEN, JENIS, DAN JUMLAH MIKROBIA DALAM RUMEN SAPI JAWA DAN PERANAKAN ONGOLE
}

\section{CHARACTERISTICS OF THE RUMEN FLUIDS, TYPE AND NUMBER OF RUMINAL MICROBES IN JAVA AND ONGOLE GRADE BULLS}

\author{
Endang Purbowati*, Edy Rianto, Wayan Sukarya Dilaga, Christina Maria Sri Lestari, dan Retno \\ Adiwinarti
}

Fakultas Peternakan dan Pertanian, Universitas Diponegoro, Kampus drh. Soejono Koesoemowardojo, Tembalang, Semarang, 50275

\section{INTISARI}

Tujuan penelitian ini adalah untuk memperoleh informasi tentang karakteristik cairan rumen, jenis, dan jumlah mikrobia yang terdapat pada rumen sapi Jawa dan sapi Peranakan Ongole (PO) jantan. Materi penelitian berupa 12 sampel cairan rumen (6 dari sapi Jawa jantan dan 6 dari sapi PO jantan) yang diambil dari rumah potong hewan (RPH) di Brebes, Jawa Tengah. Variabel yang dianalisis adalah $\mathrm{pH}, \mathrm{NH}_{3}$, dan volatile fatty acids (VFA), serta mikrobia yang terdapat di dalamnya yang dibedakan menjadi: protozoa, bakteri, dan fungi. Data yang diperoleh ditampilkan secara deskriptif. Hasil penelitian menunjukkan, bahwa $\mathrm{pH}$ cairan rumen sapi Jawa $(6,83)$ sedikit lebih tinggi dari pada sapi PO $(6,67)$, namun keduanya masih dalam kondisi yang normal. Konsentrasi $\mathrm{NH}_{3}$ cairan rumen sapi Jawa $(8,75$ $\mathrm{mgN} / 100 \mathrm{ml})$ lebih tinggi dari pada sapi PO $(7,49 \mathrm{mgN} / 100 \mathrm{ml})$. Konsentrasi asetat dan butirat cairan rumen sapi Jawa lebih rendah dari pada sapi PO, tetapi konsentrasi propionat cairan rumen sapi Jawa lebih tinggi dari pada sapi PO. Rasio asetat-propionat cairan rumen sapi Jawa lebih rendah dari pada sapi PO. Jumlah protozoa cairan rumen pada sapi Jawa (64,12 per $\mu$ l cairan rumen) lebih rendah dari pada sapi PO (76,33 per $\mu$ l cairan rumen). Populasi bakteri cairan rumen sapi Jawa $\left(2,7 \times 10^{7} \mathrm{cfu} / \mathrm{g}\right)$ lebih rendah dari pada sapi PO $\left(2,3 \times 10^{8} \mathrm{cfu} / \mathrm{g}\right)$, tetapi populasi jamur cairan rumen sapi Jawa $\left(9,3 \times 10^{4} \mathrm{cfu} / \mathrm{g}\right)$ lebih tinggi dari pada sapi PO $\left(1,9 \times 10^{3} \mathrm{cfu} / \mathrm{g}\right)$. Kesimpulan penelitian ini adalah $\mathrm{pH}$ cairan rumen kedua sapi netral, tetapi konsentrasi $\mathrm{NH}_{3}$, asam propionat dan populasi jamur cairan rumen sapi Jawa lebih tinggi dari pada sapi PO, sehingga rasio asam asetat-propionat pada sapi Jawa menjadi lebih rendah yang berarti lebih berpeluang untuk menghasilkan produktivitas berupa pertambahan bobot badan yang lebih tinggi.

(Kata kunci: Karakteristik cairan rumen, Mikrobia rumen, Sapi Jawa, Sapi PO)

\section{ABSTRACT}

The purpose of this study was to obtain data on the characteristics of rumen fluids, type and the number of microbes in Java and Ongole Grade $(O G)$ bulls rumen. The material used in the study were 12 samples of the rumen fluids (6 of Java bulls and 6 of OG bulls) collected from the slaughter house in Brebes, Central Java. The rumen fluids were analyzed for the $\mathrm{pH}, \mathrm{NH}_{3}$, volatile fatty acids (VFA) and microbes content which could be divided into: protozoa, bacteria and fungi. The data were analyzed descriptively. The results showed that the value of pH rumen fluid of Java bulls (6.83) was slightly higher than those in the OG bulls (6.67), but both were still in normal condition. $\mathrm{NH}_{3}$ concentration of Java bulls' rumen fluid $(8.75 \mathrm{mg} \mathrm{N} / 100 \mathrm{ml})$ was higher than those of the OG bulls $(7.49 \mathrm{mg} \mathrm{N} / 100 \mathrm{ml})$. Concentration of acetate and butyrate of Java bulls' rumen fluid was lower than those of the OG bulls, but the propionate concentration was higher. The acetate-propionate ratio of Java bulls' rumen fluid was lower than those of the OG bulls. Number of protozoa in Java bulls' rumen fluid (64.12 per $\mu$ l of rumen fluid) was lower than those in the OG bulls (76.33 per $\mu$ l of rumen fluid). The number of Java rumen fluid bacteria $\left(2.7 \times 10^{7} \mathrm{cfu} / \mathrm{g}\right)$ was lower than those in the $O G\left(2.3 \times 10^{8} \mathrm{cfu} / \mathrm{g}\right)$, but the amount of Java rumen fluid fungi $\left(9.3 \times 10^{4} \mathrm{cfu} / \mathrm{g}\right)$ was higher than those of the OG $\left(1.9 \times 10^{3} \mathrm{cfu} / \mathrm{g}\right)$. It was concluded that the $\mathrm{pH}$ of rumen fluid in either bulls were neutral, but the $\mathrm{NH}_{3}$ concentration, propionate acid and the number of fungi in the rumen fluid of Java was higher than those of the OG, so that the acetatepropionate ratio was lower in Java which showed that Java cattle has the potential to produce higher weight gain.

(Key words: Characteristics of the rumen fluid, Ruminal microbes, Java bulls, OG bull)

\footnotetext{
* Korespondensi (corresponding author):

Telp. +628122908694

E-mail: purbowati@hotmail.com
} 


\section{Pendahuluan}

Pemerintah mencanangkan program swasembada daging sapi pada tahun 2010, yang kemudian direvisi menjadi tahun 2014. Keberhasilan program pemerintah tersebut akan tercapai apabila seluruh sumberdaya ternak di Indonesia dieksplorasi untuk kemudian dikembangkan. Selain itu, pemerintah juga mencanangkan bahwa tahun 2010 menjadi tahun keanekaragaman hayati, artinya kekayaan flora maupun fauna bangsa Indonesia mulai mendapat perhatian pemerintah dan akan dilestarikan. Berdasar pada dua hal tersebut, maka pilihan untuk meneliti sapi Jawa yang merupakan salah satu plasma nutfah sapi Indonesia sangat tepat, sebagai pijakan dasar untuk melestarikan dan mengembangkan bangsa sapi tersebut. Apalagi dari tahun ke tahun sapi Jawa semakin terpinggirkan, digantikan bangsa sapi jenis lain seperti sapi Peranakan Ongole (PO) atau bangsa sapi impor seperti Simmental, Brahman, dan Limousin.

Penelitian tentang produktivitas sapi Jawa sudah banyak dilakukan. Hasil penelitian Lestari et al. (2009) menunjukkan bahwa sapi Jawa yang dipelihara petani peternak di kabupaten Brebes mempunyai produksi karkas yang tinggi dan kualitas daging yang baik dengan kandungan lemak yang rendah (2\%). Purbowati et al. (2011) melaporkan, bahwa sapi Jawa yang hanya diberi jerami padi dan dedak padi menghasilkan pertambahan bobot badan harian $(\mathrm{PBBH}) 0,19 \mathrm{~kg}$, sedangkan yang diberi jerami padi, dedak padi, daun gliricidia, dan mineral dapat menghasilkan PBBH sebesar $0,63 \mathrm{~kg}$. Produktivitas tersebut merupakan hasil akhir dari proses pemberian pakan dan metabolisme di dalam tubuh sapi. Namun informasi tentang kondisi cairan rumen maupun mikrobia yang terdapat dalam saluran pencernaan tersebut, khususnya pada sapi Jawa masih jarang diperoleh, bahkan boleh dikatakan tidak ada. Padahal sapi Jawa tersebut mampu memanfaatkan pakan yang berkualitas kurang baik (rumput lapang dan jerami) menjadi produk daging. Hal ini tidak lepas dari kondisi dan peran mikrobia rumen yang sangat penting dalam pencernaan pakan. Informasi tentang karakteristik cairan rumen sangat bermanfaat dalam manajemen pemberian pakan. Pemberian pakan yang sesuai dengan kebutuhan ternak, akan memberikan jaminan terhadap kelangsungan hidup ternak, khususnya apabila ternak tersebut dipelihara di luar habitat aslinya (ex situ). Sapi Jawa yang terdapat di kabupaten Brebes, merupakan plasma nutfah yang harus dilestarikan, bahkan kalau mungkin di-kembangkan tidak hanya di kabupaten Brebes, namun juga di tempat-tempat lain. Informasi yang diperoleh dari penelitian ini akan menjadi dasar untuk melestarikan dan mengembangkan sapi Jawa, sebagai bangsa sapi lokal yang kompetitif.

Tujuan penelitian ini adalah untuk memperoleh informasi tentang karakteristik cairan rumen sapi Jawa dan sapi PO. Diharapkan hasil penelitian ini dapat memberikan informasi dasar tentang kemampuan sapi Jawa tersebut dalam memanfaatkan pakan yang berkualitas jelek menjadi produk daging, dibandingkan dengan sapi lokal lain yaitu sapi PO.

\section{Materi dan Metode}

Materi penelitian berupa 12 sampel cairan rumen yang terdiri atas 6 sampel cairan rumen sapi Jawa jantan dan 6 sampel cairan rumen sapi Peranakan Ongole (PO) jantan yang diambil dari rumah potong hewan (RPH) di Brebes, Jawa Tengah. Kedua bangsa sapi yang digunakan mempunyai latar belakang pemeliharaan yang relatif sama yakni secara tradisional dengan pakan berupa rumput lapangan, jerami padi, dan jerami jagung, tanpa pemberian konsentrat.

Parameter yang dianalisis adalah $\mathrm{pH}, \mathrm{NH}_{3}$, dan volatile fatty acids (VFA), serta jumlah mikrobia yang terdapat di dalam cairan rumen yang dibedakan menjadi protozoa, bakteri dan fungi. Pengukuran $\mathrm{pH}$ cairan rumen dilakukan dengan $\mathrm{pH}$ indicator strips. Konsentrasi cairan rumen ditentukan dengan metode Conway (Work dan Work, 1978). Analisis VFA cairan rumen dilakukan dengan menggunakan alat gas kromatografi. Populasi protozoa dalam cairan rumen dihitung pada ruang hitung (counting chamber) setebal 0,2 mm (Diaz et al., 1993) menggunakan mikroskop dengan pembesaran 100 kali. Populasi total bakteri dan fungi cairan rumen dihitung dengan metode cawan tuang menurut prosedur Ogimoto dan Imai (1981). Data yang diperoleh ditampilkan secara deskriptif.

\section{Hasil dan Pembahasan}

Kondisi rumen sangat penting agar proses pencernaan pakan di dalam rumen dapat optimal. Hal ini karena proses pencernaan ruminansia tidak terlepas dari peran mikrobia rumen yang sangat membantu dalam proses pencernaan dan penyediaan zat makanan dan energi bagi ternak ruminansia tersebut. Kondisi cairan rumen sapi Jawa dan sapi PO disajikan pada Tabel karakteristik cairan rumen.

Nilai $\mathrm{pH}$ cairan rumen sapi Jawa $(6,83)$ sedikit lebih tinggi dari pada sapi PO $(6,67)$, namun keduanya masih dalam kondisi yang normal. Menurut Arora (1989), pH bervariasi menurut jenis 
Tabel Karakteristik cairan rumen (characteristics of the rumen fluids)

\begin{tabular}{|c|c|c|}
\hline Parameter & Sapi Jawa (Jawa bull) & $\begin{array}{l}\text { Sapi Peranakan Ongole } \\
\text { (Ongole Grade bull) }\end{array}$ \\
\hline $\mathrm{pH}$ cairan rumen ( $\mathrm{pH}$ of rumen fluid) & 6,83 & 6,67 \\
\hline $\begin{array}{l}\mathrm{NH}_{3} \text { cairan rumen }(\mathrm{mgN} / 100 \mathrm{ml})\left(\mathrm{NH}_{3} \text { of rumen }\right. \\
\text { fluid }(m g N / 100 \mathrm{ml}))\end{array}$ & 8,75 & 7,49 \\
\hline \multicolumn{3}{|l|}{$\begin{array}{l}\text { VFA cairan rumen }(\mathrm{ml} / \mathrm{Mol}) \text { (VFA of rumen fluid } \\
(\mathrm{ml} / \mathrm{Mol}))\end{array}$} \\
\hline - Asetat (acetate) & 28,98 & 30,89 \\
\hline - Propionat (propionate) & 8,18 & 6,88 \\
\hline - Butirat (butirate) & 5,02 & 5,95 \\
\hline Rasio asetat:propionat (acetate:propionate ratio) & 3,77 & 4,44 \\
\hline $\begin{array}{l}\text { Jumlah protozoa per } \mu 1 \text { cairan rumen (number of } \\
\text { protozoa/ } \mu \text { l rumen fluid) }\end{array}$ & 64,12 & 76,33 \\
\hline Jumlah bakteri (cfu/g) (number of bacteria $(c f u / g))$ & $2,7 \times 10^{7}$ & $2,3 \times 10^{8}$ \\
\hline Jumlah jamur (cfu/g) (number of fungi (cfu/g)) & $9,3 \times 10^{4}$ & $1,9 \times 10^{3}$ \\
\hline
\end{tabular}

pakan yang diberikan, namun pada umumnya dipertahankan tetap sekitar 6,8 karena adanya absorbsi asam lemak dan ammonia. Hasil penelitian Umar et al. (2011) menunjukkan bahwa pH cairan rumen sapi Madura dan sapi PO yang dipelihara secara intensif dengan pakan rumput gajah $(30 \%)$ dan konsentrat $(70 \%)$ masing-masing sebesar $8-8,4$ dan 7,6-8,4, lebih tinggi dari hasil penelitian ini. Yokoyama dan Johnson (1993) menyatakan bahwa $\mathrm{pH}$ rumen merupakan salah satu faktor yang mempengaruhi populasi mikroba di dalam rumen.

Konsentrasi $\mathrm{NH}_{3}$ cairan rumen sapi Jawa $(8,75 \mathrm{mgN} / 100 \mathrm{ml})$ lebih tinggi dari pada sapi PO $(7,49 \mathrm{mgN} / 100 \mathrm{ml})$. Seluruh protein yang berasal dari pakan, pertama kali dihidrolisis oleh mikroba rumen (Arora, 1989) menjadi peptida dan asamasam amino (Ranjhan, 1981). Asam amino kemudian difermentasi lebih lanjut melalui deaminasi menjadi asam $\alpha$-keto yang kemudian mengalami dekarboksilasi menjadi $\mathrm{CO}_{2}$, amonia, dan asam lemak rantai pendek (McDonald et al., 1988). Beberapa asam amino dapat langsung digunakan oleh bakteri untuk sintesis protein tubuhnya, tetapi amonia merupakan jumlah nitrogen larut yang utama dalam cairan rumen yang dibutuhkan oleh bakteri rumen untuk sintesis protein tubuhnya sepanjang kerangka karbon dari karbohidrat yang mudah dicerna seperti pati atau gula tersedia (Ranjhan, 1981). Konsentrasi amonia dalam cairan rumen tergantung dari kelarutan dan jumlah protein pakan untuk ternak, serta laju degradasi protein pakan (Widyobroto et al., 1995), waktu pengosongan rumen, laju penggunaan nitrogen oleh biomas mikroba rumen, dan absorbsi amonia (Djajanegara, 1983). Konsentrasi $\mathrm{NH}_{3}$ hasil penelitian ini cukup baik, karena menurut Satter dan Slayter (1974) cit. Nuswantara et al. (2006), konsentrasi $\mathrm{NH}_{3}$ yang diperlukan untuk laju sintesis protein mikroba yang maksimum berkisar antara 3$8 \mathrm{mg} / 100 \mathrm{ml}$ cairan rumen.

Konsentrasi asetat dan butirat cairan rumen sapi Jawa lebih rendah dari pada sapi PO, tetapi konsentrasi propionat cairan rumen sapi Jawa lebih tinggi dari pada sapi PO (Tabel). Volatile fatty acids yakni asam asetat, propionat, butirat, kemudian $\mathrm{CO}_{2}, \mathrm{CH}_{4}$ dan kadang-kadang laktat dan suksinat serta $\mathrm{H}_{2}$ merupakan produk akhir dari degradasi karbohidrat (Prawirokusumo, 1994). Volatile fatty acids merupakan sumber energi utama bagi ternak ruminansia (Arora, 1989). Asam asetat dan butirat merupakan sumber energi untuk oksidasi yang bersifat ketogenik, sedangkan asam propionat digunakan untuk proses glukoneogenesis atau bersifat glukogenik (Chuzaemi, 1994). Rasio asetatpropionat cairan rumen sapi Jawa lebih rendah dari pada sapi PO berarti lebih berpeluang untuk menghasilkan produktivitas berupa pertambahan bobot badan yang lebih tinggi. Umar et al. (2011) melaporkan bahwa rasio asetat-propionat sapi Madura dan Peranakan Ongole yang dipelihara secara intensif dengan konsentrat tinggi sebesar 1,85 dan 1,69. Menurut Walsh et al. (2009), peningkatan proporsi konsentrat meningkatkan kecernaan karbohidrat non struktural dan menurunkan kecernaan serat kasar sehingga rasio asetat-propionat rendah. Tingginya rasio asetatpropionat pada penelitian ini karena ternak dipelihara secara tradisional tanpa menggunakan konsentrat.

Populasi protozoa cairan rumen pada sapi Jawa $(64,12$ per $\mu 1$ cairan rumen) lebih rendah dari pada sapi PO (76,33 per $\mu 1$ cairan rumen). Menurut Church (1979), populasi protozoa dalam rumen berkisar $10^{5}-10^{6} \mathrm{sel} / \mathrm{ml}$ isi rumen atau berkisar $40-50 \%$ dari biomasa rumen dan tergantung dari pakan induk semang. Jika induk semang diberi 
pakan berserat, maka jumlah protozoa berkisar 25-33\% dari biomasa rumen (Orpin, 1984 cit. Soeharsono et al., 2010). Soeharsono et al. (2010) menyatakan bahwa pada ruminansia muda, biasanya protozoa belum ada. Protozoa baru ada dalam rumen ketika ruminansia muda tersebut kontak dengan hewan lain yang mengandung protozoa. Protozoa sangat sensitif terhadap asam, dan jumlahnya akan berkurang jika berada pada $\mathrm{pH}$ rendah. Faktor-faktor lain yang membatasi keberadaan protozoa dalam rumen menurut Vieira et al. (1984) adalah konsentrasi ammonia, kecepatan pertumbuhan bakteri, dan kandungan bahan kering dalam rumen.

Lebih rendahnya populasi protozoa cairan rumen sapi Jawa dibandingkan sapi PO tidak bisa dikatakan lebih baik atau lebih jelek, karena fungsi protozoa dalam rumen masih merupakan sesuatu yang dipertentangkan. Sebagian menyatakan bahwa protozoa tidak penting bagi pencernaan, sehingga lebih baik didefaunasi. Alasannya adalah untuk hidupnya memerlukan energi yang diambil dari nutrisi induk semang (Leng, 1987 cit. Soeharsono et al., 2010). Protozoa memangsa bakteri yang justru sangat bermanfaat dalam mencerna serat kasar, sehingga jumlah bakteri berkurang setengahnya (Yokoyama dan Johnson, 1993). Hanim et al. (2009) juga menyatakan bahwa kehadiran protozoa menurunkan jumlah bakteri dan jumlah total protein mikroba yang tinggal dalam rumen. Protozoa yang mati tidak dapat segera dimanfaatkan oleh induk semang, karena tertahan di dalam partikel-partikel besar dalam rumen. Percobaan in vitro menunjukkan bahwa protozoa mendegradasi pakan berprotein tinggi dan percobaan in vivo menunjukkan bahwa protozoa mengonsumsi protein yang mudah larut yang dapat segera dimanfaatkan oleh induk semang. Penelitian Demeyer (1979) cit. Soeharsono et al. (2010) menunjukkan bahwa domba yang didefaunasi pertumbuhannya meningkat sebesar $37 \%$, oleh karena itu protozoa sebaiknya ditekan sampai jumlah tertentu.

Pendapat lain menyatakan bahwa protozoa penting untuk pencernaan yaitu untuk mempertahankan $\mathrm{pH}$. Biasanya $\mathrm{pH}$ rumen cepat menurun apabila karbohidrat non struktural difermentasi dengan cepat. Hal ini terjadi apabila jumlah bakteri cukup tinggi. Dengan adanya protozoa, sebagian bakteri dimakan sehingga zat yang mudah difermentasi agak lambat difermentasi dan $\mathrm{pH}$ tidak menurun dengan drastis (Vieira et al, 1984). Protozoa berperan dalam mencerna hijauan berkualitas rendah dan kontribusinya mencapai 12- 20\% (Akin dan Amos 1978 cit. Soeharsono et al., 2010). Protozoa mempunyai peranan penting pada aspek tertentu dari metabolisme dalam rumen yang berhubungan dengan kesehatan dan kondisi ternak, karena protozoa dapat menurunkan nitrat dan nitrit dalam rumen (Yoshida et al., 1982), dan dalam mendegradasi beberapa mikotoksin (Kiessling et al., 1984). Walaupun hanya sedikit, ternyata protozoa mampu memproduksi asam propionat. Protozoa mampu menggunakan bahan makanan dan menyimpan polisakarida dalam bentuk amilopektin yang akan dipergunakan bila ketersediaan substrat terbatas. Dengan demikian protozoa mampu mengontrol ketersediaan substrat bagi kebutuhan pertumbuhannya. Dengan adanya kemampuan ini, maka protozoa dapat menjaga kestabilan proses fermentasi dalam rumen. Selain itu, kemampuan protozoa untuk memangsa bakteri juga akan menjaga kestabilan proses fermentasi dalam rumen (Church, 1979).

Populasi bakteri cairan rumen sapi Jawa $\left(2,7 \times 10^{7} \mathrm{cfu} / \mathrm{g}\right)$ lebih rendah dari pada sapi PO $\left(2,3 \times 10^{8} \mathrm{cfu} / \mathrm{g}\right)$, tetapi populasi jamur cairan rumen sapi Jawa $\left(9,3 \times 10^{4} \mathrm{cfu} / \mathrm{g}\right)$ lebih tinggi dari pada sapi PO (1,9 x $\left.10^{3} \mathrm{cfu} / \mathrm{g}\right)$. Menurut Arora (1989), konsentrasi bakteri pada sapi dapat mencapai $21 \times 10^{9}$ per ml cairan rumen. Bakteri dalam rumen dapat berasal dari bahan pakan maupun adanya kontak langsung dengan bahan lain yang mengandung bakteri. Bakteri merupakan mikroorganisme rumen yang dominan. Dilihat dari fungsinya, bakteri dalam rumen dapat dibagi menjadi 7 (tujuh) kelompok utama, yaitu (1) kelompok pencerna selulosa, (2) kelompok pencerna hemiselulosa, (3) kelompok pencerna pati, (4) kelompok pencerna gula, (5) kelompok pemakai laktat, (6) kelompok pembentuk metan, dan (7) kelompok bakteri proteolitik. Bakteri rumen telah beradaptasi untuk hidup pada kondisi fisik rumen relatif tetap yakni $\mathrm{pH} 5,5-7,0$ dan dalam keadaan anaerob (ada oksigen, tetapi sangat sedikit), suhu 39-40 ${ }^{\mathrm{OG}}$, dan konsentrasi produk fermentasi kontinyu, walau tidak begitu tinggi.

Lebih tingginya populasi jamur cairan rumen pada sapi Jawa dibandingkan sapi PO karena mikrobia ini selalu banyak terdapat dalam rumen ternak ruminansia yang diberi ransum basal dengan kandungan serat kasar tinggi (misalnya jerami). Hasil penelitian Lestari et al. (2009) melaporkan bahwa sebagian besar peternak sapi Jawa di Kelompok Tani Ternak (KTT) Lembu Lestari dan KTT Cikoneng Sejahtera, Kecamatan Bandarharjo Kabupaten Brebes, memelihara sapi di kandang (97\%) dan pakan yang diberikan berupa jerami jagung, sedangkan sisanya (3\%) memberikan pakan berupa jerami padi atau rumput lapangan dan campuran keduanya. Jamur ini mempunyai peranan penting dalam mencerna serat kasar (Van Soest, 1994), sehingga dapat meningkatkan konsumsi pakan. Lestari et al. (2009) menyatakan bahwa kemampuan konsumsi bahan kering (BK) sapi Jawa 
pada pemeliharaan in situ cukup tinggi yakni $3,57-4,02 \%$ dari bobot badan. Kemampuan konsumsi BK pakan pada sapi Jawa tersebut hampir sama dengan sapi Madura yang dilaporkan Umar et al. (2008) yaitu 3,61\% bobot badan, namun lebih tinggi dari sapi PO yang hanya mampu mengonsumsi pakan sebesar 3,03\% bobot badan.

\section{Kesimpulan}

Kesimpulan hasil penelitian ini adalah $\mathrm{pH}$ cairan rumen baik pada sapi Jawa maupun PO netral, tetapi konsentrasi $\mathrm{NH}_{3}$, asam propionat, dan populasi jamur cairan rumen sapi Jawa lebih tinggi dari pada sapi PO, sehingga rasio asam asetatpropionat pada sapi Jawa menjadi lebih rendah yang berarti lebih berpeluang untuk menghasilkan produktivitas berupa pertambahan bobot badan yang lebih tinggi.

\section{Ucapan Terima Kasih}

Ucapan terima kasih disampaikan kepada Direktur Penelitian dan Pengabdian kepada Masyarakat, Direktorat Jenderal Pendidikan Tinggi (DP2M Ditjen Dikti) Kementerian Pendidikan Nasional yang telah membiayai penelitian ini melalui dana penelitian Hibah Fundamental pada tahun anggaran 2011, dengan DIPA Nomor: 0596/023-04.2-16/13/2011 tanggal 20 Desember 2010. Terima kasih pula kepada A.S. Suparno dan Yoga Hudoyo yang telah membantu dalam pengambilan data di lapangan.

\section{Daftar Pustaka}

Arora, S. P. 1989. Pencernaan Mikroba pada Ruminansia. Diterjemahkan oleh: Retno Murwani. Gadjah Mada University Press, Yogyakarta.

Church, D. C. 1979. Digestive Physiology and Nutrition of Ruminants. Volume 1. $2^{\text {nd }}$ ed. Oxford Press, Portland.

Chuzaemi, S. 1994. Potensi jerami padi sebagai pakan ternak ditinjau dari kinetik degradasi dan retensi jerami di dalam rumen. Disertasi Doktor. Universitas Gadjah Mada, Yogyakarta.

Diaz, A., M. Avendano and A. Escobar. 1993. Evaluation of Sapindus saponaria as a defaunating agents and its effects on different ruminal digestion parameters. Livest. Res. Rural Dev. 5: 1-6.
Djajanegara, A. 1983. Tinjauan ulang mengenai suplemen pada jerami padi. Kumpulan Makalah Seminar. Pemanfaatan Limbah Pertanian untuk Makanan Ternak. Lembaga Kimia Nasional dan LIPI, Bandung.

Hanim, C., L. M. Yusiati and S. Alim. 2009. Effect of saponin as defaunating agent on in vitro ruminal fermentation of forage and concentrate. Jurnal Pengembangan Peternakan Tropis 34: 231-235.

Kiessling, K. H., J. Peterson, K. Sandholm and M. Olsen. 1984. Metabolism of aflatoxin, OGhratoxin, zearlenone and three trichothecenes by intact rumen fluid, rumen protozoa, and rumen bacteria. Appl. Environ. Microbiol 47: 1070.

Lestari, C. M. S., Soedarsono, A. Purnomoadi, dan E. Pangestu. 2009. Status nutrisi sapi jawa yang dipelihara petani peternak Kecamatan Bandarharjo Kabupaten Brebes (Studi Pendahuluan). Prosiding Seminar Nasional Teknologi Peternakan dan Veteriner 2009. Pusat Penelitian dan Pengembangan Peternakan, Bogor.

Nuswantara, L. K., M. Soejono, R. Utomo, B. P. Widyobroto, dan H. Hartadi. 2006. Parameter fermentasi rumen pada sapi Peranakan Friesian Holstein yang diberi pakan basal jerami padi dengan suplementasi sumber nitrogen dan energi berbeda. Jurnal Pengembangan Peternakan Tropis 31: 268275.

McDonald, P., R. A. Edward and J. F. D. Greenhalgh. 1988. Animal Nutrition. $4^{\text {th }}$ ed. John Wiley \& Sons, New York.

Ogimoto, K. and S. Imai. 1981. Atlas of Rumen Microbiology. Japan Scientific SOGieties Press, Tokyo.

Prawirokusumo, S. 1994. Ilmu Gizi Komparatif. Edisi pertama. Badan Penerbit Fakultas Ekonomi. Yogyakarta.

Purbowati, E., R. Adiwinarti, C. M. S. Lestari, E. Rianto and M. Arifin. 2011. Live weight gain and feed cost per gain of Java cattle with improved diet. The $3^{\text {rd }}$ International Conference on Sustainable Animal Agriculture for Developing Countries. School of Animal Production Technology, Suranaree University of Technology, Nakhon Ratchasima 3000, Thailand.

Ranjhan, S. K. 1981. Animal Nutrition in Tropics. $2^{\text {nd }}$ Revised Edition. Vikas Publishing House PVT LTD, New Delhi. 
Soeharsono, K. A. Kamil, dan A. Mushawwir. 2010. Sistem gastrointestinal ruminansia. Dalam: Fisiologi Ternak, Fenomena dan Nomena Dasar dari Fungsi serta Interaksi Organ pada Hewan. Soeharsono (ed.). Widya Padjadjaran, Bandung. Hal: 182-284.

Umar, M., M. Arifin, dan A. Purnomoadi. 2008. Studi komparasi produktivitas sapi Madura dengan sapi Peranakan Ongole. Prosiding Seminar Nasional Teknologi Peternakan dan Veteriner 2008. Pusat Penelitian dan Pengembangan Peternakan, Bogor.

Umar, M., M. Arifin and A. Purnomoadi. 2011. Ruminal condition between Madura cattle and Ongole Crossbred cattle raised under intensive feeding. J. Indon. Trop. Anim. Agric. 36: 213-218.

Van Soest, P. J. 1994. Nutritional Ecology of the Ruminant. Second Edition. Cornell University Press. London.

Vieira, D. M., M. Ivan and P. Y. Jui. 1984. The effect of ciliata protozoa on the flow of amino acids from the Stonmarch of sheep. Can. J. Anim. Sci. 64 (suppl): 22-23.
Walsh, K., P. O’Kiely, H. Z. Taweel, M. McGee, A. P. Moloney and T. M. Boland. 2009. Intake, digestibility and rumen characteristics in cattle offered whole-crop wheat or barley silages of contrasting grain to straw ratios. Anim. Feed Sci. Technol. 148: 192-213.

Widyobroto, B. P., S. Padmowijoto, dan R. Utomo. 1995. Pendugaan kualitas protein bahan pakan (hijauan, limbah pertanian dan konsentrat) untuk ternak ruminansia. Laporan Penelitian. Fakultas Peternakan Universitas Gadjah Mada, Yogyakarta.

Work, T. S. and E. Work. 1978. Laboratory Techniques. North Holland Publishing Co., Amsterdam.

Yokoyama, M. T. and K. A. Johnson. 1993. Microbiology of the Rumen and Intestine. In Church (ed). The Ruminant Animal. Digestive, Physiology, and Nutrition. Waveland Press, Inc., Englewood Cliffs.

Yoshida, J., Y. Nakamura and R. Nakamura. 1982. Effect of protozoal fraction and lactate on nitrate metabolism of microorganism in sheep rumen. Jpn. J. Zoottech. 53: 677-685. 